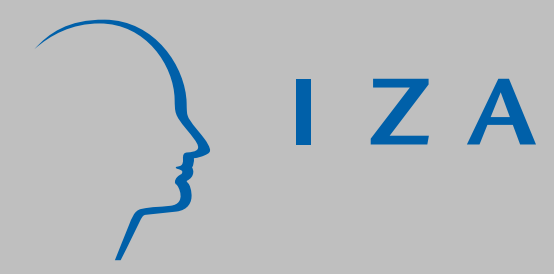

IZA DP No. 752

Skill-Biased Technological Change in Denmark: A Disaggregate Perspective

Nikolaj Malchow-Møller

J an Rose Skaksen

April 2003 


\title{
Skill-Biased Technological Change in Denmark: A Disaggregate Perspective
}

\author{
Nikolaj Malchow-Møller \\ CEBR, Copenhagen \\ Jan Rose Skaksen
Copenhagen Business School,
CEBR and IZA Bonn
}

Discussion Paper No. 752
April 2003

IZA

P.O. Box 7240

D-53072 Bonn

Germany

Tel.: +49-228-3894-0

Fax: +49-228-3894-210

Email: iza@iza.org

This Discussion Paper is issued within the framework of IZA's research area The Future of Labor. Any opinions expressed here are those of the author(s) and not those of the institute. Research disseminated by IZA may include views on policy, but the institute itself takes no institutional policy positions.

The Institute for the Study of Labor (IZA) in Bonn is a local and virtual international research center and a place of communication between science, politics and business. IZA is an independent, nonprofit limited liability company (Gesellschaft mit beschränkter Haftung) supported by the Deutsche Post AG. The center is associated with the University of Bonn and offers a stimulating research environment through its research networks, research support, and visitors and doctoral programs. IZA engages in (i) original and internationally competitive research in all fields of labor economics, (ii) development of policy concepts, and (iii) dissemination of research results and concepts to the interested public. The current research program deals with (1) mobility and flexibility of labor, (2) internationalization of labor markets, (3) welfare state and labor market, (4) labor markets in transition countries, (5) the future of labor, (6) evaluation of labor market policies and projects and (7) general labor economics.

IZA Discussion Papers often represent preliminary work and are circulated to encourage discussion. Citation of such a paper should account for its provisional character. A revised version may be available on the IZA website (www.iza.org) or directly from the author. 
IZA Discussion Paper No. 752

April 2003

\section{ABSTRACT}

\section{Skill-Biased Technological Change in Denmark: A Disaggregate Perspective*}

In this paper, we provide an industry-level analysis of skill-biased technological change (SBTC) in Denmark over the last two decades. The analysis shows that SBTC has varied considerably across industries, and traditionally large Danish industries have experienced relatively less SBTC. This may partly explain why wage inequality between skilled and less skilled has risen less in Denmark than in other countries. We also find that SBTC has been concentrated in already skill-intensive industries. This contains important information about future labour requirements, as the relative importance of these industries must be expected to grow, thereby reinforcing the shift in demand for skilled labour.

JEL Classification: J24, J31, L6

Keywords: skill-biased technological change, Danish industries

Corresponding author:

Jan Rose Skaksen

Department of Economics

Copenhagen Business School

Solbjerg Plads 3

2000 Frederiksberg

Denmark

Tel.: +45 38152582

Fax: +4538152576

E-mail: jrs.eco@cbs.dk

\footnotetext{
* The authors wish to thank Henrik Bøhm Rasmussen for research assistance, and Jan Rose Skaksen gratefully acknowledges financial support from the Danish Social Science Research Foundation.
} 


\section{Introduction}

The extent and consequences of skill-biased technological change (SBTC) have been high on the research agenda in recent decades, spurred in part by the increasing wage inequality between skilled and unskilled workers observed in the US and a number of other OECD countries. In Denmark, increases in wage inequality have so far been much less pronounced than in most AngloSaxon countries, see e.g. Malchow-Møller and Skaksen (2003). This does not, however, imply that SBTC has been absent - or even smaller - in Denmark compared to other countries. Instead, there may be several reasons why SBTC has had a different impact on labour market outcomes in Denmark.

A first explanation, as argued in Fosgerau, Jensen, and Sørensen (2000), is that the relative supply of skilled labour has increased sufficiently in Denmark to meet the changes in demand and hence prevent increasing wage inequality. A second possible explanation is that due to relative wages being determined by institutions rather than the market, the rising inequality in Denmark has been reflected in employment opportunities rather than wages, see MalchowMøller and Skaksen (2003), who show that the employment rates of unskilled workers have been decreasing relative to those of skilled workers. ${ }^{1}$ A third possible explanation is that the actual skills of the formally unskilled workers are higher in Denmark than in comparable countries, as documented by OECD (2000). Yet a fourth possibility is that different skills are required across industries. A special industrial composition of the Danish economy may then explain why SBTC has had different effects on aggregate labour demand in Denmark compared to other countries.

Different approaches have been used in the literature to formally assess the amount and nature of SBTC in Denmark as well as in other countries. From a political perspective, determining the extent of SBTC is highly important - not only to reap the full benefits of technological progress, but also to avoid increasing inequality between the skilled and the less skilled in the future.

In this paper, we start by reviewing existing studies of labour demand changes in Denmark, trying to reconcile the somewhat mixed evidence in terms of the differences in methods used. Since all existing studies are undertaken at an aggregate level, we then proceed with a disaggregate analysis of labour demand changes in Denmark over the last decades. This will add to our understanding of the extent to which aggregate labour demand changes

\footnotetext{
${ }^{1}$ The employment rate is defined as the share of individuals in the population having a job, corrected for working time. The employment rate is used instead of the unemployment rate, since the latter concept is strongly biased by institutional constructs such as the formal possibility of early retirement.
} 
are driven by economy-wide SBTC or by SBTC in a subset of industries. It will also reveal whether the limited changes in wage inequality in Denmark can in part be explained by a different industrial composition. Furthermore, knowing the industrial differences may give important information about the specific skills demanded in the future as well as of future comparative advantages. As far as Denmark is a skill-intensive country, it is likely that industries in which SBTC has been most pronounced are industries, in which Danish companies will be able to compete and expand in the future.

Following a similar logic, Haskel and Slaughter (2002) have shown theoretically that if SBTC takes place in unskill-intensive industries, then it might actually lower the relative demand for skilled workers as these industries become more competitive and increase their overall labour demand. In support of this theory, they find - using data on 10 OECD countries for the 1970s and 1980s - that the skill premium was generally rising (falling) in periods/countries where SBTC was concentrated in skill-intensive (unskillintensive) industries.

In this paper, we focus exclusively on Denmark, providing a more detailed study of industrial differences and their importance for aggregate labour demand using data from 1980 through 1998. To assess industrial labour demand changes, we use both a method developed by Katz and Murphy (1992) as well as a method similar in spirit to that of Haskel and Slaughter (2002), but using a classification of workers based on education rather than job specification. As shall be argued in Section 2, these methods contain important complementary information about the extent of labour demand changes and hence SBTC.

It should be stressed at the outset that SBTC is not the only possible cause of an increasing relative demand for skilled labour. Alternative explanations are increasing international trade with especially developing countries, see, e.g., Leamer (1998), and international outsourcing of activities which are intensive in the use of unskilled labour, see, e.g., Feenstra and Hanson (2001). However, by performing a standard factor content analysis, Malchow-Møller and Skaksen (2003) find that it is unlikely that international trade in final goods has had a big impact on the relative demand for skilled labour in Denmark. If anything, their analysis shows that international trade in final goods has given rise to an increasing demand for unskilled labour in Denmark. With respect to international outsourcing, Skaksen and Sørensen (2002) find that in the 1980s and 1990s, international outsourcing is responsible for an increasing relative demand for skilled labour, but the effect has been rather modest: In sum, it seems safe to assume that SBTC is by far the most important cause of labour demand changes.

The rest of the paper is structured as follows. Section 2 reviews existing 
studies of labour demand changes in Denmark at the aggregate level, explaining the differences between the two main approaches used. In Section 3, we present some descriptive statistics of industrial differences in wages and employment of skilled and unskilled workers. This is followed in Section 4 by more formal analyses of labour demand changes at the industrial level. Section 5 concludes the paper.

\section{Aggregate Labour Demand Changes in Den- mark}

Since labour market outcomes are affected by both demand and supply factors, it is difficult to obtain useful measures of changes in relative labour demand and SBTC. An often used indirect measure is the change in the skilled-labour share of the total wage bill. ${ }^{2}$ In some analyses, skilled labour is defined as non-manual labour, whereas in other studies, skilled labour refers to a minimum level of schooling such as, e.g., a college education. ${ }^{3}$

By using a measure which is closely related to the change in the share of the total wage bill paid to skilled (educated) labour, Fosgerau, Jensen, and Sørensen (2000) find that changes in labour demand in the private sector in Denmark in the 1980s and 1990s have been similar to those in the US. The reason why relative wages for skilled labour in Denmark have not been increasing to the same extent as in the US is - according to Fosgerau, Jensen, and Sørensen (2000) - that the supply of skilled labour has increased more in Denmark than in the US.

Considering the change in the share of the wage sum paid to educated labour is only one possible "test" of changes in labour demand, and unless wages are reasonably flexible, there is a risk that an increase in the supply of educated labour always becomes interpreted as a change in demand. If wages are inflexible, e.g., because of the influence of trade unions, the wages of educated do not necessarily drop in response to an increase in their supply. Instead, some educated workers may be forced to accept unskilled jobs below their qualifications - a phenomenon known as overeducation. ${ }^{4}$ In this case, the wage share of educated labour rises in response to a supply increase and is therefore not a very useful measure of the actual demand for educated

\footnotetext{
${ }^{2}$ As demonstrated in Haskel and Slaughter (2002), most of the other indirect measures are closely correlated with this measure.

${ }^{3}$ Autor, Katz, and Krueger (1998) amongst others use the latter approach, whereas, e.g., Berman, Bound, and Machin (1998) and Haskel and Slaughter (2002) define skilled labour as non-manual labour.

${ }^{4}$ See Green, McIntosh, and Vignoles (1999) for an overview of this literature.
} 
workers. A similar effect would be observed in a case with high substitutability between educated and uneducated workers, e.g., because of high actual skills of uneducated workers.

Malchow-Møller and Skaksen (2003) use a different method to test for changes in relative labour demand in Denmark; a method which is less vulnerable to hidden effects of overeducation. The method, which was originally developed by Katz and Murphy (1992), is based on the fact that under an unchanged labour demand function, an increase in the relative employment of a certain type of labour should be associated with a decrease in its relative wage. In other words: The relative demand function is downward sloping. ${ }^{5}$ Hence, if firms tend to employ relatively more of those types of labour for which relative wages have been increasing and/or less of those types of labour for which relative wages have been decreasing, this reveals that a change in the relative demand for labour - a shift in the labour demand function must have occurred.

Basing their analysis on 168 different types of labour, Malchow-Møller and Skaksen (2003) only find weak indications of labour demand changes in Denmark in the 1980s and 1990s. One possible explanation is that the test builds on the information contained in relative wage changes. With a labour market in Denmark characterised by inflexible relative wages, an increase in the demand for educated labour might show up as less unemployment rather than higher wages. Therefore, Malchow-Møller and Skaksen (2003) develop a modified test based on the information in the development of unemployment rates rather than relative wages. Using this test, they find some indications of labour demand changes in favour of the educated in Denmark. In other words, labour demand shifts have made it increasingly difficult for unskilled labour to become employed in Denmark.

To summarise, both Fosgerau, Jensen, and Sørensen (2000) and MalchowMøller and Skaksen (2003) find that Denmark in the 1980s and 1990s has been characterised by a shift in labour demand towards more skilled labour. However, there seems to be some disagreement concerning the extent of these changes. Fosgerau, Jensen, and Sørensen (2000) find that the changes have been similar to what has been found for the US, whereas Malchow-Møller and Skaksen (2003) find that the evidence for Denmark is less convincing. One possible reason for this discrepancy in results is that the two analyses are based on rather different approaches. Whereas the approach taken by Fosgerau, Jensen, and Sørensen (2000) probably tends to exaggerate labour demand shifts in an economy with inflexible relative wages, the approach

\footnotetext{
${ }^{5}$ This result follows from standard economic theory under the assumption that firms act as cost minimisers.
} 
used by Malchow-Møller and Skaksen (2003) tends to underestimate demand shifts in such an economy.

Another important difference between the two analyses is that Fosgerau, Jensen, and Sørensen (2000) rely exclusively on data from the private sector, whereas Malchow-Møller and Skaksen (2003) use data on the entire economy. It is likely that demand shifts have been more pronounced in the private sector than in the public sector.

Both analyses, however, apply a very aggregate perspective on labour demand changes, which conceivably hides important insight at the more disaggregate level. In the following, we therefore undertake an analysis of relative labour demand shifts across different industries in the Danish economy.

\section{Industrial Wages and Employment, 1980- 1998}

The analyses of this paper are based on data from the IDA database from Statistics Denmark (2000), which cover the entire Danish population for the period 1980-98. We define skilled labour as workers holding at least a short further (tertiary) education, and we divide the economy into 25 (public and

private) industries. Table 1 reports the yearly growth in the relative wage of skilled labour in each of these industries. In order to control for composition effects within the groups of skilled and unskilled labour, respectively, fixed weights with respect to the distribution of workers on 168 demographic subgroups, defined by age, gender, educational level and type, are used. In this way, we eliminate the effects on, e.g., the average wage level of skilled workers which are due to more skilled workers becoming older and/or more educated. Table 1 also contains the skilled share and the change in the skilled share of total employment in each industry.

Measured by employment shares, the most skill-intensive industries are: "Pharmaceuticals", "Electricity, gas and water supply", and "Software and consultancy services", plus the four public industries at the bottom of the Table. Employment shifts in favour of skilled labour are observed in nearly all industries in both the 1980s and the 1990s. Furthermore, the total change is higher in the 1990s compared to the 1980s. However, looking at the changes in the relative wages of skilled labour, these were increasing in 21 out of 25 industries in the 1980s (all industries in the private sector), but only in 12 industries in the 1990s. Taken together, these observations seem to indicate some ambiguity concerning the importance of SBTC in the 1990s compared to the 1980s. 
Although the changes in employment shares support economy-wide demand shifts, there are considerable differences across industries. In, e.g., "Pharmaceuticals" and "Software and consultancy services", the changes in the skilled employment shares are high in both periods, whereas in, e.g., "Construction", it is low in both periods.

Table 1: Relative employment shares and wage changes

\begin{tabular}{|c|c|c|c|c|c|}
\hline & \multirow{2}{*}{$\begin{array}{c}\text { Skilled- } \\
\text { labour share } \\
\text { of total } \\
\text { employment } \\
1980 \\
\end{array}$} & \multicolumn{2}{|c|}{$\begin{array}{l}\text { Change in skilled- } \\
\text { labour share of total } \\
\text { employment }\end{array}$} & \multicolumn{2}{|c|}{$\begin{array}{l}\text { Yearly growth in } \\
\text { relative wage of skillec } \\
\text { labour (per cent) }\end{array}$} \\
\hline & & 1980-89 & $1989-98$ & 1980-89 & 1989-98 \\
\hline Primary sector & 0.103 & 0.092 & 0.048 & 0.855 & 0.403 \\
\hline \multicolumn{6}{|l|}{ Manufacturing } \\
\hline Food products, beverages and tobacco & 0.044 & 0.017 & 0.026 & 1.148 & -0.129 \\
\hline Textiles and clothing & 0.025 & 0.017 & 0.059 & 1.507 & -0.278 \\
\hline Wood and products of wood & 0.046 & 0.010 & 0.028 & 1.105 & 0.036 \\
\hline Chemicals, chemical- and rubber products & 0.105 & 0.015 & 0.061 & 0.639 & 0.098 \\
\hline Pharmaceuticals & 0.252 & 0.076 & 0.116 & 0.531 & -0.316 \\
\hline Construction materials & 0.073 & 0.014 & 0.025 & 0.720 & 0.078 \\
\hline Fabricated metal products & 0.095 & 0.014 & 0.032 & 0.913 & -0.214 \\
\hline Equipment and apparatus & 0.095 & 0.029 & 0.029 & 1.225 & -0.415 \\
\hline $\begin{array}{l}\text { Electricity, gas and water supply etc., } \\
\text { sanitation and similar activities }\end{array}$ & 0.198 & 0.009 & -0.051 & 0.911 & 0.945 \\
\hline \multicolumn{6}{|l|}{ Trade and services } \\
\hline Sale and maintenance of motor vehicles & 0.017 & 0.004 & 0.013 & 0.495 & -0.092 \\
\hline Wholesale trade & 0.097 & 0.023 & 0.060 & 0.979 & 0.036 \\
\hline Retail trade & 0.046 & 0.007 & 0.019 & 0.668 & -0.478 \\
\hline Hotels and restaurants & 0.018 & 0.014 & 0.019 & 0.750 & 0.063 \\
\hline Cleaning, business- and other services & 0.086 & 0.035 & 0.050 & 0.859 & 0.470 \\
\hline Construction & 0.064 & 0.011 & 0.017 & 0.583 & -0.568 \\
\hline Transport, post and telecommunications & 0.069 & 0.011 & 0.031 & 0.115 & 0.080 \\
\hline Financial intermediation & 0.074 & 0.047 & 0.055 & 0.456 & -0.189 \\
\hline Real estate and renting & 0.114 & 0.010 & -0.003 & 0.582 & -1.494 \\
\hline Software and consultancy services & 0.323 & 0.061 & 0.104 & 0.211 & -0.380 \\
\hline Publishing & 0.102 & 0.028 & 0.062 & 0.039 & 0.120 \\
\hline \multicolumn{6}{|l|}{ Public sector } \\
\hline Public services & 0.215 & 0.011 & 0.091 & -0.206 & -0.138 \\
\hline Education & 0.672 & -0.018 & 0.023 & -0.150 & -0.060 \\
\hline Health care & 0.359 & 0.114 & 0.079 & -1.001 & 0.775 \\
\hline Social work & 0.217 & 0.059 & 0.026 & -0.822 & 1.006 \\
\hline Total & 0.171 & 0.035 & 0.048 & 0.201 & -0.089 \\
\hline
\end{tabular}

Source: Statistics Denmark (2000) and own calculations 
While the numbers in Table 1 give a first indication of the pattern of labour demand changes and hence SBTC in the 1980s and 1990s, the following Section presents more formal analyses of labour demand changes in each of the 25 industries.

\section{Labour Demand Changes at the Industry Level}

In this Section, we present two tests of labour demand changes - interpreted as SBTC - for each of the 25 industries. The first test is that of Katz and Murphy (1992), described in Section 2, whereas the second test is based on the information contained in the changes in the skilled share of the total wage bill. As argued in Section 2, these two tests complement each other in an economy characterised by inflexible relative wages.

Results of the "Katz and Murphy tests" are presented in Table 2, where a " + " indicates that the test confirms that a shift in labour demand has occurred over the period, while a "-" indicates that such a shift cannot be supported by the data. ${ }^{6}$

From 1980 to 1989, demand changes are identified in 20 out of 25 industries, whereas in the 1990s, the number of industries with demand changes is only 8 . This confirms that demand shifts have been more pronounced in the 1980s. In only six industries do we find demand shifts in both periods, including the skill-intensive industries: "Software and consultancy services" and "Health care". Within another skill-intensive industry, "Pharmaceuticals", where one in particular would expect to find demand shifts, these are only confirmed for the first period.

As mentioned above, there is probably a bias in the "Katz and Murphy test" towards not confirming labour demand shifts in an economy like the Danish where relative wages are less flexible than in, e.g., the US. Moreover, the test only provides little information concerning the nature of the demand shifts. In principle, these could be in favour of the unskilled rather than the skilled. For these reasons, we also include an analysis which builds on the information in the relative wage sum paid to skilled and unskilled

\footnotetext{
${ }^{6}$ In Table 2, 1980 is an average for 1980-84, 1989 an average for 1987-91, and 1998 an average for 1994-98. By analysing changes between averages of 5-year intervals, transitory fluctuations in employment and wages are eliminated. A more detailed description of the test can be found in Katz and Murphy (1992) or Malchow-Møller and Skaksen (2003). Strictly speaking, a "+" in Table 2 indicates that the null hypothesis of an unchanged demand is rejected.
} 
labour. Similar approaches have been applied in a number of analyses, and our presentation follows closely Haskel and Slaughter (2002). ${ }^{7}$

Table 2: Katz and Murphy tests for changes in labour demand

\begin{tabular}{|c|c|c|}
\hline & $1980-89$ & 1989-98 \\
\hline Primary sectors & - & + \\
\hline \multicolumn{3}{|l|}{ Manufacturing } \\
\hline Food products, beverages and tobacco & + & - \\
\hline Textiles and clothing & + & - \\
\hline Wood and products of wood & - & + \\
\hline Chemicals, chemical- and rubber products & + & + \\
\hline Pharmaceuticals & + & - \\
\hline Construction materials & - & - \\
\hline Fabricated metal products & + & - \\
\hline Equipment and apparatus & + & - \\
\hline $\begin{array}{l}\text { Electricity, gas and water supply etc., } \\
\text { sanitation and similar activities }\end{array}$ & + & - \\
\hline \multicolumn{3}{|l|}{ Trade and services } \\
\hline Sale and maintenance of motor vehicles & + & - \\
\hline Wholesale trade & + & - \\
\hline Retail trade & + & - \\
\hline Hotels and restaurants & + & + \\
\hline Cleaning, business- and other services & + & - \\
\hline Construction & - & - \\
\hline Transport, post and telecommunications & + & + \\
\hline Financial intermediation & + & - \\
\hline Real estate and renting & + & + \\
\hline Software and consultancy services & + & + \\
\hline Publishing & + & - \\
\hline \multicolumn{3}{|l|}{ Public sector } \\
\hline Public services & + & - \\
\hline Education & + & - \\
\hline Health care & + & + \\
\hline Social work & - & + \\
\hline
\end{tabular}

Source: Statistics Denmark (2000) and own calculations

Production is assumed to depend on the input of capital, skilled labour and unskilled labour. Capital is assumed to be a quasi-fixed factor, and the functional form of the cost function is given by the translog function with a constant returns to scale production technology, see, e.g., Diewert (1974). Minimising costs with respect to the input of unskilled and skilled labour

\footnotetext{
${ }^{7}$ See also Katz and Murphy (1992), Autor, Katz and Krueger (1998) and Fosgerau, Jensen and Sørensen (2001) for related approaches at the aggregate level.
} 
implies that the change in the share of the wage sum paid to skilled labour over some period is:

$$
\Delta \omega_{k}=a_{0}+a_{1} \Delta \log \left(\frac{w_{s}}{w_{u}}\right)_{k}+a_{2} \Delta \log \left(\frac{K}{Y}\right)_{k}+\varepsilon_{k}
$$

where $\Delta$ is the first-difference operator, $\omega_{k}$ is the share of the wage sum paid to skilled labour in industry $k,\left(\frac{w_{s}}{w_{u}}\right)_{k}$ is the relative wage of skilled labour in industry $k,\left(\frac{K}{Y}\right)_{k}$ is the capital-output ratio, $\varepsilon_{k}$ is an error term, and the $a_{i}$ 's are parameters to be estimated. Now, $a_{0}$ becomes a measure of average SBTC, while $a_{0}+\varepsilon_{k}$ becomes a measure of SBTC in industry $k$.

Since we do not have capital data at the industry level, we assume that the capital-output ratio is constant in each industry, $\Delta \log \left(\frac{K}{Y}\right)_{k}=0$, implying that:

$$
\Delta \omega_{k}=a_{0}+a_{1} \Delta \log \left(\frac{w_{s}}{w_{u}}\right)_{k}+\varepsilon_{k}
$$

Estimating (2) by OLS yields $\hat{a}_{0}$ as an estimate of average SBTC across industries, and $\hat{a}_{0}+\hat{\varepsilon}_{k}$ as an estimate of SBTC in industry $k$. The resulting estimates are presented in Table 3 for the two periods.

Table 3 reveals that with a few exceptions, SBTC is identified in all industries in both periods. Furthermore, the amount of SBTC in the 1990s appears to be no less than in the 1980s, as opposed to the results from the more conservative Katz and Murphy test in Table 2, which showed a decline in SBTC in the 1990s.

The reason why the Katz and Murphy test detects only limited SBTC in the 1990s is the less favourable wage development for the skilled in this period, as seen from Table 1. The Katz and Murphy test requires a combination of positive wage and employment developments for skilled workers relative to unskilled workers to reject a hypothesis of no SBTC. The measures of SBTC in Table 3, on the other hand, are based on the shares of the total wage bill, where changes can come about also as a consequence of supply changes, as discussed in Section 2. Taken together, the two analyses thus seem to indicate a decline in SBTC in the 1990s.

This may signal a decrease in the tendency for SBTC, but it might also be a consequence of the positive business cycle in most of the 1990s. The idea is that skill upgrading mainly occurs when labour is easily available as it is the case in downturns. Analysing the Danish manufacturing sector, Skaksen and Sørensen (2002) actually confirm the hypothesis that businesscycle movements have statistically significant effects on skill upgrading in Danish companies. 
Table 3: Estimates of skill-biased technological change (SBTC)

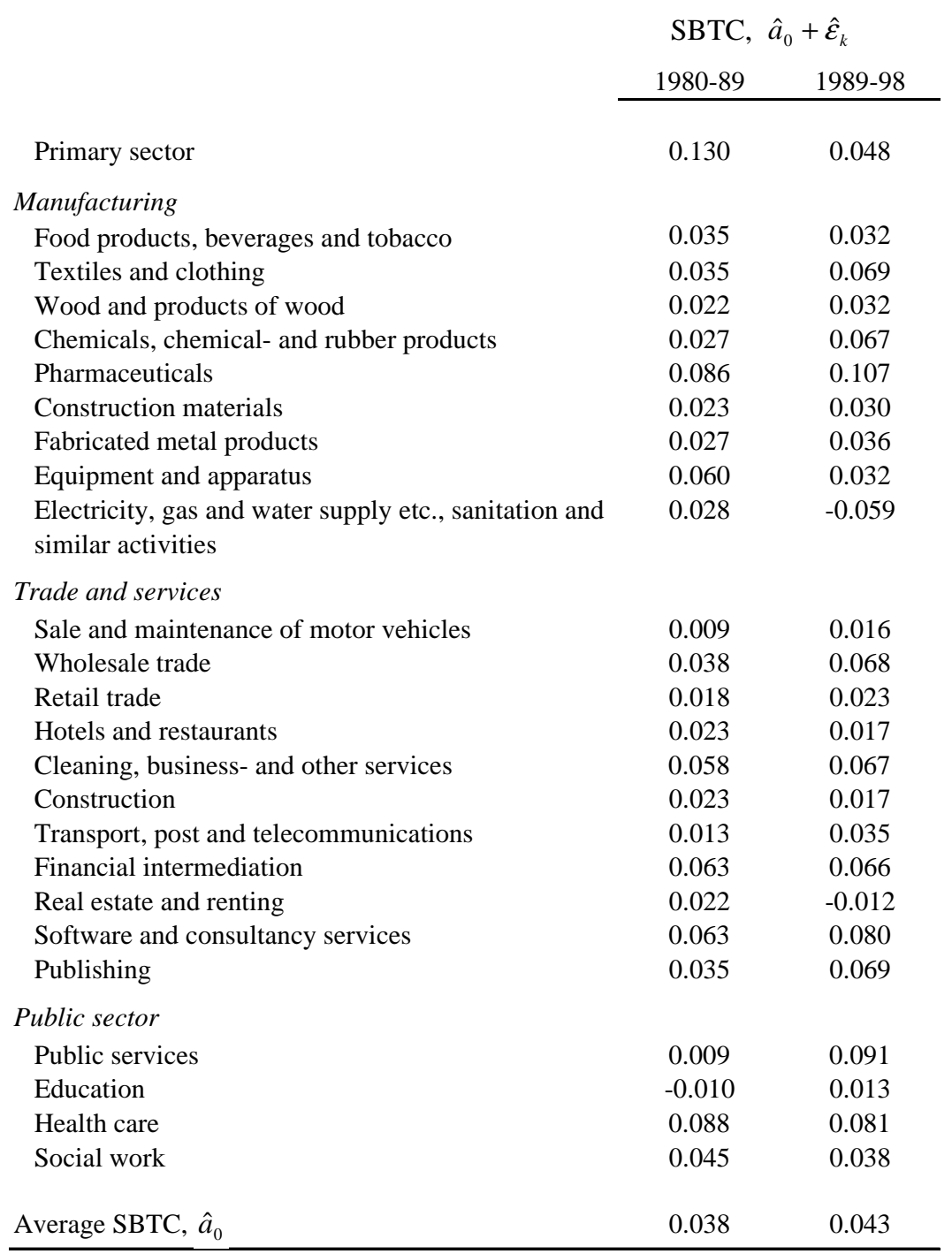

Source: Statistics Denmark (2000) and own calculations

Compared to the Katz and Murphy test, which does not contain information about the size of the effects, the numbers in Table 3 indicate large variation across industries. In, e.g., "Software and consultancy services", "Pharmaceuticals", "Financial intermediation" and "Cleaning, business- and other services", SBTC has been considerable compared to, e.g., "Construction" and "Transport". This holds potential for explaining why a specific industrial composition in Denmark may have induced different labour demand at the aggregate level compared to other countries. By international standards, 
"Food products, beverages and tobacco" and "Fabricated metal products" are relatively large industries in Denmark, responsible for 17,0\% and 23,5\%, respectively, of total production in manufacturing, whereas the averages in the OECD area are $11,9 \%$ and $17,9 \%$, see OECD (2001). Since these industries have experienced SBTC below the average level, this may explain why aggregate SBTC and labour demand changes have been less pronounced in Denmark.

From a dynamic perspective, one might presume that those industries having experienced most SBTC will gain competitiveness and expand over time. Following the argument of Haskel and Slaughter (2002), we might thus expect that if SBTC has taken place mostly in skill-intensive industries then these industries will grow and raise the overall demand for skills. On the other hand, if SBTC takes place in unskill-intensive industries, then it might actually induce less demand for skills over time. As an example, consider the "Software and consultancy services" industry in Table 3. It has experienced relatively large amounts of SBTC in both periods, and accordingly its share in total employment went up from $2,86 \%$ in 1980 to $3,66 \%$ in 1989 to $4,52 \%$ in $1998 .^{8}$ A similar story can be told about "Pharmaceuticals" which has grown from $0,3 \%$ to $0,6 \%$ of total employment since 1980 .

In order to obtain more systematic information on these issues, we regress the obtained measure of SBTC on a measure of skill-intensity in industry $k$ :

$$
S B T C_{k}=\alpha+\beta \frac{S_{k}}{U_{k}}+\gamma_{1} D_{t s}+\gamma_{2} D_{p u b}+\varepsilon_{k}
$$

where $S B T C_{k}$ is measured by $\hat{a}_{0}+\hat{\varepsilon}_{k}, \frac{S_{k}}{U_{k}}$ is the total skilled wage bill relative to the unskilled wage bill, and $D_{t s}$ and $D_{p u b}$ are dummy variables for the trade and service sector and the public sector, respectively. As the public sector may be very different from the private sector, we also run the regression without the observations from the public sector:

$$
S B T C_{k}=\alpha+\beta \frac{S_{k}}{U_{k}}+\gamma_{1} D_{t s}+\varepsilon_{k}
$$

Finally, the regression in (3) is also run without the "Education" industry, since this industry is an outlier which contains a much higher share of skilled employment than any other industry and therefore probably has less room for skill-upgrading. Table 4 contains the results of these three regressions for both the 1980s and 1990s (with and without dummies included).

As soon as the education industry is omitted, the picture appears pretty clear: $\beta$ is significantly positive in most regressions. This indicates that skill-

\footnotetext{
${ }^{8}$ Source: Statistics Denmark (2000) and own calculations.
} 
upgrading has been most pronounced in already skill-intensive industries, such as "Pharmaceuticals" and "Software and Consultancy Services", and therefore that a further increase in demand for skilled labour can be expected as these industries grow in the future.

Table 4: Estimates of industry bias of SBTC

\begin{tabular}{|c|c|c|c|c|c|c|c|}
\hline \multirow[b]{2}{*}{ 1980s } & \multirow[b]{2}{*}{$\alpha$} & \multicolumn{2}{|c|}{ All industries } & \multicolumn{2}{|c|}{$\begin{array}{c}\text { Excluding } \\
\text { public sector }\end{array}$} & \multicolumn{2}{|c|}{$\begin{array}{c}\text { Excluding } \\
\text { "Education" }\end{array}$} \\
\hline & & $\begin{array}{c}0.041 * * \\
(5.823)\end{array}$ & $\begin{array}{c}0.049 * * \\
(4.774)\end{array}$ & $\begin{array}{c}0.027 * * \\
(3.185)\end{array}$ & $\begin{array}{c}0.034^{* *} \\
(3.210)\end{array}$ & $\begin{array}{c}0.027 * * \\
(3.400)\end{array}$ & $\begin{array}{c}0.032 * * \\
(3.161)\end{array}$ \\
\hline & $\beta$ & $\begin{array}{c}-0.008 \\
(-0.725)\end{array}$ & $\begin{array}{c}-0.008 \\
(-0.597)\end{array}$ & $\begin{array}{c}0.073 * * \\
(2.120)\end{array}$ & $\begin{array}{l}0.071^{*} \\
(2.058)\end{array}$ & $\begin{array}{c}0.063 * * \\
(2.488)\end{array}$ & $\begin{array}{c}0.082 * * \\
(2.680)\end{array}$ \\
\hline & $\gamma_{1}$ & & $\begin{array}{c}-0.014 \\
(-1.043)\end{array}$ & & $\begin{array}{c}-0.013 \\
(-1.100)\end{array}$ & & $\begin{array}{l}-0.012 \\
(-1.085)\end{array}$ \\
\hline & $\gamma_{2}$ & & $\begin{array}{c}-0.006 \\
(-0.290)\end{array}$ & & & & $\begin{array}{c}-0.029 \\
(-1.424)\end{array}$ \\
\hline & Obs. & 25 & 25 & 21 & 21 & 24 & 24 \\
\hline $1990 \mathrm{~s}$ & $\alpha$ & $\begin{array}{c}0.040 * * \\
(4.591)\end{array}$ & $\begin{array}{c}0.040 * * \\
(3.184)\end{array}$ & $\begin{array}{c}0.026^{* *} \\
(2.368)\end{array}$ & $\begin{array}{c}0.024 \\
(1.672)\end{array}$ & $\begin{array}{c}0.028 * * \\
(2.926)\end{array}$ & $\begin{array}{l}0.027 * \\
(2.038)\end{array}$ \\
\hline & $\beta$ & $\begin{array}{c}0.004 \\
(0.310)\end{array}$ & $\begin{array}{c}-0.005 \\
(-0.260)\end{array}$ & $\begin{array}{c}0.058 \\
(1.718)\end{array}$ & $\begin{array}{c}0.059 \\
(1.690)\end{array}$ & $\begin{array}{c}0.052 * * \\
(2.208)\end{array}$ & $\begin{array}{c}0.047 \\
(1.616)\end{array}$ \\
\hline & $\gamma_{1}$ & & $\begin{array}{c}0.001 \\
(0.066)\end{array}$ & & $\begin{array}{c}0.004 \\
(0.238)\end{array}$ & & $\begin{array}{c}0.003 \\
(0.209)\end{array}$ \\
\hline & $\gamma_{2}$ & & $\begin{array}{c}0.021 \\
(0.755)\end{array}$ & & & & $\begin{array}{c}0.010 \\
(0.386)\end{array}$ \\
\hline & Obs. & 25 & 25 & 21 & 21 & 24 & 24 \\
\hline
\end{tabular}

Notes: t-statistics in parentheses. $* *=$ significant at $5 \%$ level. $*=$ significant at $10 \%$ level

Source: Statistics Denmark (2000) and own calculations

Perhaps surprisingly, the dummy for the public sector, $\gamma_{2}$, is insignificant in all regressions. Thus, systematic differences between public and private industries cannot be detected as soon as the "Education" industry is left out of the analysis. ${ }^{9}$

\section{Conclusion}

The analyses of this paper have documented that labour demand shifts have occurred to various degrees in most industries in the Danish economy. The

\footnotetext{
${ }^{9} \mathrm{~A}$ probit analysis using the results of the Katz and Murphy test as the dependent indicator variable was also undertaken. Though the coefficient of $\frac{S_{k}}{U_{k}}$ was positive in 11 out of 12 regressions, it was not significant.
} 
differences across industries contain important information in both explaining current labour market outcomes and predicting future labour requirements. Thus, the relatively large importance in Denmark of industries which have experienced only limited amounts of SBTC may explain why inequality between the skilled and unskilled has risen less in Denmark than in many other OECD countries.

At the same time, the fact that demand shifts have been more pronounced in skill-intensive industries may signal an increased competitiveness/profitability of these industries, and hence over time an increase in their relative importance at the expense of less skill-intensive industries, thereby reinforcing the shift in demand for skilled labour. Though more in-debt analyses are required, a first tentative conclusion seems to be that more skilled labour will definitely be needed in the future. 


\section{References}

Autor, D., L. Katz, And A. Krueger (1998): "Computing Inequality: Have Computers Changed the Labor Market?," Quarterly Journal of Economics, 113, 1169-1214.

Berman, E., J. Bound, And S. Machin (1998): "Implications of SkillBiased Technical Change: International Evidence," Quarterly Journal of Economics, 113, 1245-1280.

Diewert, W. E. (1974): "Applications of Duality Theory," in Frontiers of Quantitative Economics, Vol. II, ed. by M. Intriligator, and D. Kendrick, pp. 106-171. North-Holland, Amsterdam.

Feenstra, R., and G. Hanson (2001): "Global Production Sharing and Rising Inequality: A Survey of Trade and Wages," NBER Working Paper No. 8372.

Fosgerau, M., S. E. H. Jensen, and A. Sørensen (2000): "Relative Demand Shifts for Educated Labour," CEBR Discussion Paper 2000-11.

Green, F., S. McIntosh, and A. Vignoles (1999): "Overeducation and Skills - Clarifying the Concepts," Centre for Economic Performance Discussion Paper No. 435, London School of Economics.

Haskel, J. E., And M. J. Slaughter (2002): "Does the Sector Bias of Skill-Biased Technical Change Explain Changing Skill Premia?," European Economic Review, 46, 1757-1783.

Katz, L. F., And K. M. Murphy (1992): "Changes in Relative Wages, 1963-1987: Supply and Demand Factors," Quarterly Journal of Economics, 107, 35-78.

Leamer, E. (1998): "In Search of Stolper-Samuelson Linkages Between International Trade and Lower Wages," in Imports, Exports, and the American Worker, ed. by M. Susan, pp. 141-202. Brookings Institution Press, Washington DC.

Malchow-Møller, N., and J. R. Skaksen (2003): "Globalisering og ulighed på det danske arbejdsmarked," CEBR report 2003-1.

OECD (2000): "Literacy in the Information Age," Final Report of the International Adult Literacy Survey, OECD, Paris.

(2001): "Indicators of Industry and Services," OECD, Paris. 
Skaksen, J. R., and A. Sørensen (2002): "Skill Upgrading and Rigid Relative Wages: The Case of Danish Manufacturing," CEBR Discussion Paper 2002-08.

Statistics Denmark (2000): "IDA Database 1980-98," Copenhagen, Denmark. 


\section{IZA Discussion Papers}

No.

Author(s)

737

738

739

740

741

742

743

744

745

746

747

748

749

750

751

752
A. L. Booth
M. Francesconi
G. Zoega

\section{Grossmann}

M. Fertig

B. T. Hirsch

S. L. Mehay

B. T. Hirsch

D. A. Macpherson

R. A. Easterlin

G. Heineck

J. Schwarze

M. R. West

L. Woessmann

L. Woessmann
A. Ammermueller
H. Heijke
L. Woessmann

J. Messina

M. Pflüger

V. Jakobsen

N. Smith

R. Hujer

M. Caliendo

S. Thomsen

L. Borghans

B. ter Weel

N. Malchow-Møller J. R. Skaksen
Title

Area

Date

Unions, Work-Related Training, and Wages:

3

03/03

Evidence for British Men

Managerial Job Assignment and Imperfect

Competition in Asymmetric Equilibrium

Who's to Blame? The Determinants of German

Students' Achievement in the PISA 2000 Study

Evaluating the Labor Market Performance of

Veterans Using a Matched Comparison Group

Design

Wages, Sorting on Skill, and the Racial

Composition of Jobs

Building a Better Theory of Well-Being

3

03/03

Substance Use and Earnings: The Case of

Smokers in Germany

Which School Systems Sort Weaker Students

into Smaller Classes? International Evidence

Educational Production in East Asia: The Impact of Family Background and Schooling Policies on Student Performance

Schooling Quality in Eastern Europe:

Educational Production During Transition

4

$03 / 03$

Sectoral Structure and Entry Regulations

3

$03 / 03$

Economic Integration, Wage Policies and Social 2

Policies

The Educational Attainment of the Children of 1

the Danish 'Guest Worker' Immigrants

New Evidence on the Effects of Job Creation

Schemes in Germany - A Matching Approach with Threefold Heterogeneity

Are Computer Skills the New Basic Skills? The

Returns to Computer, Writing and Math Skills in Britain

Skill-Biased Technological Change in Denmark:

A Disaggregate Perspective
6

04/03

5

$04 / 03$

$04 / 03$

$04 / 03$

5

$04 / 03$

An updated list of IZA Discussion Papers is available on the center's homepage www.iza.org. 